Table 1. Crystal radii of actinide and lanthanide ions

\begin{tabular}{|c|c|c|c|c|c|c|}
\hline \multirow{2}{*}{$\begin{array}{l}\text { No. of } f \text { - } \\
\text { electrons }\end{array}$} & \multicolumn{6}{|c|}{ Crystal radii of ions (A.) } \\
\hline & \multicolumn{2}{|c|}{ Thoride series } & \multicolumn{2}{|c|}{ Actinide series } & \multicolumn{2}{|c|}{ Lanthanide series } \\
\hline $\begin{array}{l}0 \\
1 \\
2 \\
3 \\
4 \\
5 \\
6\end{array}$ & $\begin{array}{l}\mathrm{Th}^{4}+ \\
\mathrm{Pa}^{4}+ \\
\mathrm{U}^{4}+ \\
\mathrm{Np}^{4}+ \\
\mathrm{Pu}^{4}+ \\
\mathrm{Am}^{4}+\end{array}$ & $\begin{array}{c}0.95 \\
(0.91) \\
0.89 \\
0.88 \\
0.86 \\
0.85\end{array}$ & $\begin{array}{c}\mathrm{Ac}^{3}+ \\
\left(\mathrm{Th}^{3}+\right. \\
\left(\mathrm{Pa}^{3}+\right. \\
\mathbf{U}^{3}+ \\
\mathrm{Np}^{3+}+ \\
\mathrm{Pu}^{3+} \\
\mathrm{Am}^{3+}+\end{array}$ & $\begin{array}{l}1 \cdot 11 \\
1 \cdot 08) \\
1 \cdot 06) \\
1 \cdot 04 \\
1 \cdot 02 \\
1 \cdot 01 \\
1 \cdot 00\end{array}$ & $\begin{array}{l}\mathrm{La}^{3+} \\
\mathrm{Ce}^{3+} \\
\mathbf{P r}^{3+} \\
\mathbf{N d}^{3+}\end{array}$ & $\begin{array}{l}1 \cdot 04 \\
1.02 \\
1 \cdot 00 \\
0.99\end{array}$ \\
\hline
\end{tabular}

The valencies of the actinide elements are shown in Table 2, together with those of the corresponding rare earths.

Table 2. Valencies of the actinides and lanthanides

$\begin{array}{cl}\text { Element } & \text { Valencies } \\ \text { Ac } & 3 \\ \text { Th } & 4,(3),(2) \\ \mathbf{P a} & 5,4 \\ \text { U } & 6,5,4,3 \\ \mathrm{~Np} & 6,5,4,3 \\ \mathrm{Pu} & 6,5,4,3 \\ \mathrm{Am} & 4 \text { or } 5,3,2 \\ \mathrm{Cm} & 3\end{array}$
Element Valencies

$\begin{array}{ll}\text { La } & 3 \\ \text { Ce } & 4,3 \\ \text { Pr } & 5,4,3 \\ \text { Nd } & (4), 3 \\ \text { Tc } & 3 \\ \text { Sm } & 3,2 \\ \text { Eu } & 3,2 \\ \text { Gd } & 3\end{array}$

Values are in some cases higher than for the rare earths, which reflects the looser binding of the $5 f$-electrons and their more ready promotion to the valency shell. Between uranium and curium there is an increase in stability of the lower valency states, and it is remarkable that americium can be reduced by sodium amalgam to the bivalent state, which resembles the corresponding states of samarium and europium. Both americium and curium resemble the rare earths rather closely, and are best separated from them by the use of ion exchange resins. Numerous compounds of the new actinide elements, and of plutonium in particular, have now been described, and, although their radioactivity and the resulting need for special facilities may render them inaccessible to most laboratories, the chemistry of these substances will undoubtedly shortly be as well known as that of most other elements.

Much less has been published as yet on the chemistry of francium, astatine, prometheum and technetium, the other four new elements mentioned earlier. Astatine in the form of the isotope $\mathrm{At}_{85}^{211}$, an $\alpha$-active substance of $7 \cdot 5$-hr. half-life, has, however, been used in tracer studies which have given a general picture of its chemistry. The element itself may be extracted from solution with organic solvents and thus resembles iodine. There is also definite evidence from ion migration experiments that it can form negative ions, which are probably analogous to the iodide and iodate ions. The intense $\alpha$-activity of astatine will, however, render the study of its chemistry on anything approaching a macro scale a matter of very great difficulty. The missing rareearth element of atomic number 61 has now been clearly identified by its X-ray emission spectrum. It is formed in fission and also in cyclotron reactions, and has been separated with the aid of ion exchange resins. There is, however, no reason to expect that the chemistry of the element will differ substantially from that of the other rare earths. In the case of technetium, at least milligram quantities of one of the long-lived radioactive isotopes have already been prepared, and, in view of its position between manganese and rhenium in the periodic table, the element and its compounds are likely to be of very great interest to the chemist.

\section{BIOCHEMICAL ASPECTS OF GENETICS IN"=}

T was often emphasized by the late Sir Frederick 1 Gowland Hopkins a study of the individual cell and of the orgfnisation of chemical reactions within the chil the true objective of biochemistry. The relationship of genetic constitution to chemical aqfivitybis, in such a connexion, a matter of first inflaftance; but it was not until some ten years ago that investigations of this nature could be applied experimentally to unicellular organisms. Following a proper advance in technique, derived largely from the work of Beadle and Tatum, corresponding advances have taken place in the elucidation of genetico-biochemical problems.

The symposium organised recently by the Bio. chemical Society upon "Biochemical Aspects of Genetics" would have delighted Hopkins, for he was convinced that in this direction lay the biochemistry of the future. Sufficient indication was available from the pioneer work of such investigators as Garrod and Onslow on multicellular organisms that there awaited a rich harvest to be gathered in the fullness of time, and the discussion here reported has further endorsed such an expectation.

The symposium was so organised that in the morning session, under the chairmanship of Prof. J. B. S. Haldane, the development was reviewed of our knowledge of colour inheritance and pigment production in flowers and the interpretation of chemical abnormalities encountered in man. The afternoon session, under Dr. A. Neuberger, dealt with chemical methods of inducing mutation, the relation between gene action and mutation, between spatial pattern as the geneticist understands it and the time sequences of biochemical processes, and finally with the problem of the relationship existing between genetic differences and the production of adaptive enzymes in micro-organisms. A wide field was thus covered, which served to point to problems for future resolution as well as frequently to indicate striking identity of conclusion by workers in the biochemical and genetical laboratory respectively.

That a simple relation must exist between genes and enzymes is, of course, an assumption essential to all this work on biochemical genetics; but the exact form of such relationship has still to be determined -whether, for example, one particular gene controls the elaboration of one particular enzyme, or whether the gene itself may not, indeed, be identified with the enzyme in question. The bulk of experimental and clinical evidence is in favour of the former one-to-one hypothesis; but it seems that the question of identity or otherwise, may not be finally answerable unti we know much more concerning the nature of adaptive enzymes and the mechanism of theil formation.

Considering now in more detail each of the con tributions to this symposium, W. J. C. Lawrence described how Onslow's suggestion that in Antir. rhinum majus anthocyanins were derived from anthoxanthins led to the later investigations at the John Innes Institution which demonstrated that anthocyanin production was controlled as regards amount, state of oxidation, degree of methylatior and glucosidal type by simple gene relationships, as were also flavone and chalkone production. Further it was shown that in Dahlia, competition could exist between the production of anthocyanin, flavone and 
chalkone, according to gene dosage, implying the parallel production of these materials from a common precursor, a view which had previously been put forward on purely theoretical grounds by Robinson.

Prof. L. S. Penrose set forth Garrod's fundamental conception of certain disease states or metabolic anomalies as inborm errors of metabolism, and showed how such an analysis enabled an explanation to be given for the first time by Garrod of the special significance of inbreeding in man.

Prof. C. Rimington pointed out that Garrod's interpretation of familial conditions as being due to the lack of a particular enzyme essential for the completion of a certain stage in normal intermediary metabolism is probably correct in the case of alcaptonuria, and cited good evidence for believing tyrosinosis and phenylketonuria to be similarly interpretable. In familial methæmoglobinæmia, deficiency of a co-enzyme factor in the erythrocytes of affected persons has actually been demonstrated by Gibson. Certain of the conditions studied by Garrod, notably cystinuria, are better interpreted, however, as errors of retention or excretion. Thus cystine is only one of a group of substances showing some chemical similarity which are demonstrable in cystinuric urine, and it would appear that in this condition the kidney is unable to re-absorb certain constituents from the glomerular filtrate. A precisely similar explanation has been given by Friedman and Byers for the excretion of uric acid by the Dalmatian $\mathrm{dog}$, and these workers produce compelling experimental evidence in support of their view.

The different classes of substance which are available for the chemical induction of mutationmustards, carcinogenetic hydrocarbons, etc.-were discussed by Dr. J. G. Carr, who pointed out that all are radiomimetic. As yet no substances have been discovered which will react with only one gene.

Dr. D. G. Catcheside analysed the relationship between gene action and mutation. Some extreme mutations, in which loss of activity appears to be complete under all conditions within which the organism is viable, can back-mutate or revert to the wild type. This must mean that an almost intact gene, capable of reproduction, must have persisted. The most probable postulate is that specificity has been retained, but that the enzyme produced by the mutant gene suffers from a restricted stability, for example, as regards temperature or $p H$. In other cases back-mutations never occur.

Dr. G. Pontecorvo, after describing the modern techniques for the genetical study of moulds, bacteria, protozoa, etc., posed the question whether or not spectral organisation of genetical architecture is related to the time sequence of biochemical steps it controlled, in some such way as are operations along assembly lines. There is some suggestion that this may be so, but further specifically planned investigation is needed to prove this point.

In the concluding contribution, Dr. J. Monod dealt with the phenomenon of adaptation encountered in bacteria, and showed how, for example, in $E$. coli ML, a lactose-splitting enzyme, lactase, and a maltosesplitting enzyme, amylomaltase, may be induced to form within the cells by cultivating them upon the respective substrates. The same two enzymes are subject to genetic control, as is seen from spontaneous and induced mutations. These latter are independent of the state of adaptation of the cells.
It is clear that much remains to be done before such fundamental processes of the cell as those under discussion at this symposium are fully understood, but that already biochemistry and genetics have joined in a partnership from which both are bound to profit immeasurably.

C. Rimington

\section{THREE HISTORTCAL NOTES}

$$
\begin{gathered}
\text { By DR. D. McKIE } \\
\text { Unirersity College, London } \\
\text { Boyle's Library }
\end{gathered}
$$

7 HE Hon. Robert Boyle died on December 30, 1691, and some curiosity has been expressed from time to time in recent years about what was done with his books after his death. In that valuable bibliographical study of Boyle that has made every student of seventeenth-century science his debtor, Prof. John Fulton quoted an entry for April 1, 1692, from a diary, now in the Bodleian and possibly by Zachary Merrill, to the effect that Boyle's library contained "330 fol. 801 qtos. 2440 Oct and 12. most of $y^{\mathrm{m}}$ well bound. They may be had for 3 or $400 £$ (tho' worth 1000) because they must not be sold by Auction"1. It was a considerable collection. Later, Fulton quoted $^{2}$ a further reference through the discovery by Mr. J. C. Hindle, of the Bodleian, of an advertisement dated July 9, [1692], stating that: "The Library of the Honourable Robert Boyle, Esq ; lately Deceased, will be sold by Retail, on Monday the 11th. of this Instant July: Any Gentlemen or Others, may have the opportunity to View, and Buy what they please, at reasonable Rates. Attendance will be given at the late Lady Ranelaugh's House in the Pell-Mell, near St. James's, on Monday, Tuesday and Thursday next, from Nine a Clock in the Morning till Seven at Night." In explanation of the reference to "PellMell", it is known that Boyle lived with his sister, Lady Ranelagh, in her house in Pall Mall; she predeceased him by a week.

From this announcement, says Fulton, the library was not sold until July 1692, and then not by auction, but privately. It would seem, therefore, that booksellers and others were invited to buy from the collection lots or items in which they were interested.

Recently a copy of Becher's "Novum Organum Philologicum" (Francofurti ad Mœnum, 1674) came into my hands with the inscription on the reverse of the fly-leaf, "R Hooke pd 2ld. Mar.25.1693MF.", since verified as being in Hooke's handwriting. Reference to the fragment of Hooke's diary for 168893 confirmed the details of the inscription; for under that date he had recorded, "In MF Paid 1.9d for Bechers Novum Organum philologicum"s. Further reference to the diary for the same period brought to light a number of other interesting entries which indicate that Boyle's library was dispersed.

Two days before he bought Becher's book, Hooke "in MF saw many of Mr Boyles German chemicall books, also Bechers word-book"', which suggests that this copy of Becher's book may well have belonged to Boyle before Hooke, since Becher was a wellknown writer on chemistry and since it was a scientific book, a kind of thesaurus of scientific terms in Latin and German. Boyle did not, so far as is known, have a book-plate and he did not inscribe his name in his books. 